\title{
Reporter Genes
}

A Practical Guide 


\section{METHODS IN MOLECULAR B IOLOG YTM}

\section{John M. Walker, SERIES EDITOR}

436. Avian Influenza Virus, edited by Erica Spackman, 2008

435. Chromosomal Mutagenesis, edited by Greg Davis and Kevin J. Kayser, 2008

434. Gene Therapy Protocols: Vol. 2: Design and Characterization of Gene Transfer Vectors, edited by Joseph M. LeDoux, 2008

433. Gene Therapy Protocols: Vol. 1: Production and In Vivo Applications of Gene Transfer Vectors, edited by Joseph M. LeDoux, 2008

432. Organelle Proteomics, edited by Delphine Pflieger and Jean Rossier, 2008

431. Bacterial Pathogenesis: Methods and Protocols, edited by Frank DeLeo and Michael Otto, 2008

430. Hematopoietic Stem Cell Protocols, edited by Kevin D. Bunting, 2008

429. Molecular Beacons: Signalling Nucleic Acid Probes, Methods and Protocols, edited by Andreas Marx and Oliver Seitz, 2008

428. Clinical Proteomics: Methods and Protocols, edited by Antonio Vlahou, 2008

427. Plant Embryogenesis, edited by Maria Fernanda Suarez and Peter Bozhkov, 2008

426. Structural Proteomics: High-Throughput Methods, edited by Bostjan Kobe, Mitchell Guss, and Huber Thomas, 2008

425. 2D PAGE: Vol. 2: Applications and Protocols, edited by Anton Posch, 2008

424. 2D PAGE: Vol. 1: Sample Preparation and Pre-Fractionation, edited by Anton Posch, 2008

423. Electroporation Protocols, edited by Shulin Li, 2008

422. Phylogenomics, edited by William J. Murphy, 2008

421. Affinity Chromatography: Methods and Protocols, Second Edition, edited by Michael Zachariou, 2008

420. Drosophila: Methods and Protocols, edited by Christian Dahmann, 2008

419. Post-Transcriptional Gene Regulation, edited by Jeffrey Wilusz, 2008

418. Avidin-Biotin Interactions: Methods and Applications, edited by Robert J. McMahon, 2008

417. Tissue Engineering, Second Edition, edited by Hannsjörg Hauser and Martin Fussenegger, 2007

416. Gene Essentiality: Protocols and Bioinformatics, edited by Svetlana Gerdes and Andrei L. Osterman, 2008

415. Innate Immunity, edited by Jonathan Ewbank and Eric Vivier, 2007

414. Apoptosis in Cancer: Methods and Protocols, edited by Gil Mor and Ayesha Alvero, 2008
413. Protein Structure Prediction, Second Edition, edited by Mohammed Zaki and Chris Bystroff, 2008

412. Neutrophil Methods and Protocols, edited by Mark T. Quinn, Frank R. DeLeo, and Gary M. Bokoch, 2007

411. Reporter Genes: A Practical Guide, edited by Don Anson, 2007

410. Environmental Genomics, edited by Cristofre C. Martin, 2007

409. Immunoinformatics: Predicting Immunogenicity In Silico, edited by Darren R. Flower, 2007

408. Gene Function Analysis, edited by Michael Ochs, 2007

407. Stem Cell Assays, edited by Vemuri C. Mohan, 2007

406. Plant Bioinformatics: Methods and Protocols, edited by David Edwards, 2007

405. Telomerase Inhibition: Strategies and Protocols, edited by Lucy Andrews and Trygve O. Tollefsbol, 2007

404. Topics in Biostatistics, edited by Walter T. Ambrosius, 2007

403. Patch-Clamp Methods and Protocols, edited by Peter Molnar and James J. Hickman, 2007

402. PCR Primer Design, edited by Anton Yuryev, 2007

401. Neuroinformatics, edited by Chiquito J. Crasto, 2007

400. Methods in Membrane Lipids, edited by Alex Dopico, 2007

399. Neuroprotection Methods and Protocols, edited by Tiziana Borsello, 2007

398. Lipid Rafts, edited by Thomas J. McIntosh, 2007

397. Hedgehog Signaling Protocols, edited by Jamila I. Horabin, 2007

396. Comparative Genomics, Vol. 2, edited by Nicholas H. Bergman, 2007

395. Comparative Genomics, Vol. 1, edited by Nicholas H. Bergman, 2007

394. Salmonella: Methods and Protocols, edited by Heide Schatten and Abraham Eisenstark, 2007

393. Plant Secondary Metabolites, edited by Harinder P. S. Makkar, P. Siddhuraju, and Klaus Becker, 2007

392. Molecular Motors: Methods and Protocols, edited by Ann O. Sperry, 2007

391. Methicillin-Resistant Staphylococcus aureus (MRSA) Protocols, edited by Yinduo Ji, 2007

390. Protein Targeting Protocols, Second Edition, edited by Mark van der Giezen, 2007

389. Pichia Protocols, Second Edition, edited by James M. Cregg, 2007 


\title{
METHODS IN MOLECULAR BIOLOGYTM
}

\section{Reporter Genes}

\author{
A Practical Guide
}

\section{Edited by \\ Donald S. Anson}

Department of Genetic Medicine, Women's and Children's Hospital, Adelaide, Australia

Humana Press 落 Totowa, New Jersey 
(c) 2007 Humana Press Inc.

999 Riverview Drive, Suite 208

Totowa, New Jersey 07512

\section{www.humanapress.com}

All rights reserved. No part of this book may be reproduced, stored in a retrieval system, or transmitted in any form or by any means, electronic, mechanical, photocopying, microfilming, recording, or otherwise without written permission from the Publisher. Methods in Molecular Biology ${ }^{\mathrm{TM}}$ is a trademark of The Humana Press Inc.

All papers, comments, opinions, conclusions, or recommendations are those of the author(s), and do not necessarily reflect the views of the publisher.

This publication is printed on acid-free paper. $\infty$

ANSI Z39.48-1984 (American Standards Institute)

Permanence of Paper for Printed Library Materials.

Cover illustration: Figure 1, Chapter 11, "Green Fluorescent Protein as a Tracer in Chimeric Tissues," by Harold Jockusch and Daniel Eberhard.

Production Editor: Michele Seugling

Cover design by Karen Schulz

For additional copies, pricing for bulk purchases, and/or information about other Humana titles, contact Humana at the above address or at any of the following numbers: Tel.: 973-256-1699; Fax: 973-256-8341; E-mail: humana@humanapr.com; or visit our Website: www.humanapress.com

\section{Photocopy Authorization Policy:}

Authorization to photocopy items for internal or personal use, or the internal or personal use of specific clients, is granted by Humana Press Inc., provided that the base fee of US $\$ 30.00$ per copy is paid directly to the Copyright Clearance Center at 222 Rosewood Drive, Danvers, MA 01923. For those organizations that have been granted a photocopy license from the CCC, a separate system of payment has been arranged and is acceptable to Humana Press Inc. The fee code for users of the Transactional Reporting Service is: [978-1-58829-739-6/07 \$30.00].

Printed in the United States of America. 10987654321

e-ISBN: 978-1-60327-072-4

Library of Congress Cataloging-in-Publication Data

Reporter genes : a practical guide / edited by Donald S. Anson.

p. ; cm. - (Methods in molecular biology ; 411)

Includes bibliographical references and index.

ISBN-13: 978-1-58829-739-6 (alk. paper) 1. Reporter genes. 2. Mammals-Cytology. 3. MammalsGenetics. I. Anson, Donald.

II. Series: Methods in molecular biology (Clifton, N.J.); v.411.

[DNLM: 1. Genes, Reporter. 2. Cytological Techniques. 3. Mammals-genetics.

W1 ME9616J v.411 2007 / QU 470 R425 2007]

QH447.8.R47R47 2007

$572.8 ' 19-\mathrm{dc} 22$ 


\section{Preface}

Reporter genes have played, and continue to play, a vital role in many areas of biological research by providing a ready means for qualitative and quantitative assessment of the activity of genes and location of gene products in different environments. For example, reporter genes have played a major role in defining the activity of different genetic elements that control transcription of genes, both in vitro and in vivo $(1,2)$, in the study of cell lineages $(2,3)$ and in determining the effectiveness of different gene transfer technologies $(4,5)$. While early reporter genes required fixation of cells for visualization, or the preparation of cell extracts for quantitative assays, there has been a move towards reporter genes that can be assayed quantitatively and/or qualitatively in live cells and animals. The two widely used examples of such markers are the fluorescent proteins $(6-8)$ and luciferase $(9,10)$. However, despite the development of these new reporter genes, one of the earliest, $E$. coli $\beta$-galactosidase (LacZ), is still widely used as a marker and offers significant advantages, especially for histological analysis (11).

Most reporter genes originate from non-mammalian species, and most have subsequently been modified to enhance their expression in mammalian cells and/or to modify their characteristics, vastly increasing their usefulness. For example, codon optimisation for expression in mammalian cells has been applied to the fluorescent proteins (12), luciferase (13) and $\beta$-galactosidase (14). The characteristics of fluorescent proteins have been extensively modified, with variants of many different colours and characteristics now available $(\mathbf{1 5 , 1 6}$ and see chapter by Patterson in this book). $\operatorname{LacZ}(14,17,18)$ and fluorescent proteins $(\mathbf{1 8 , 1 9 )}$ can also be targeted to the nucleus of cells by addition of suitable trafficking signals. Fluorescent proteins are also widely used for making fusion proteins to allow analysis of sub-cellular trafficking and compartmentalisation of proteins of interest $(2,20,21)$.

Reporter genes have provided powerful tools for analysis of gene expression, either by localisation and/or by quantitative analysis. Examples of the former include the use of LacZ, where staining of microscopic sections gives information on gene expression at cellular resolution, and fluorescent proteins, where direct visualisation of tissue can give similar information. The use of luciferase as a marker gene in vivo also results in information regarding the localisation of gene expression in the living animal, although at a much lower resolution. In this system in vivo gene expression can be quantified by photonic imaging (see chapter by Ray and Gambhir). 
Most marker genes can be used to provide quantitative data regarding gene expression. However, in some cases this requires the preparation of cell lysates. For example, $\beta$-galactosidase (LacZ) can be quantified by ELISA or enzyme activity and kits for this are available from a number of manufacturers, as are kits for quantitative analysis of several other enzymatic reporter genes such as alkaline phosphatase and luciferase. Reporter genes that can be quantitatively assayed without the preparation of a cell lysate include luciferase (via photonic imaging), secreted alkaline phosphatase (enzyme assay) and fluorescent proteins (via FACS analysis or microscopy).

New marker/reporter gene systems are currently being developed. For example, systems based on the use of positron-emission tomography (PET) offer a means for non-invasive imaging of all tissues $(\mathbf{2 2 , 2 3 )}$. While these are not covered in this book, the development of microPET machines suitable for imaging rodents means that this technology is likely to be rapidly developed over the next few years. As indicated above, molecular engineering is constantly being used to improve existing reporter systems.

This book will describe practical protocols for experimentation with the most useful reporter genes for mammalian systems that are available and will concentrate on those marker genes that are currently most commonly used.

Donald S. Anson

\section{References}

1. Mayer-Kuckuk, P., Menon, L. G., Blasberg, R. G., Bertino, J. R., and Banerjee, D. (2004) Role of reporter gene imaging in molecular and cellular biology. Biol. Chem. 385, 353-361.

2. Yu, Y. A., Szalay, A. A., Wang, G., and Oberg, K. (2003) Visualization of molecular and cellular events with green fluorescent proteins in developing embryos: a review. Luminescence 18, 1-18.

3. Trainor, P. A., Zhou, S. X., Parameswaran, M., et al. (1999) Application of lacZ transgenic mice to cell lineage studies. Methods Mol. Biol. 97, 183-200.

4. Bogdanov, A. Jr. (2003) In vivo imaging in the development of gene therapy vectors. Curr. Opin. Mol. Ther. 5, 594-602.

5. McCaffrey, A., Kay, M. A., and Contag, C. H. (2003) Advancing molecular therapies through in vivo bioluminescent imaging. Mol. Imaging 2, 75-86.

6. Hoffman, R. M. (2005) Advantages of multi-color fluorescent proteins for wholebody and in vivo cellular imaging. J. Biomed. Opt. 10, 41202-1-41202-10.

7. Passamaneck, Y. J., Di Gregorio, A., Papaioannou, V. E., and Hadjantonakis, A. K. (2006) Live imaging of fluorescent proteins in chordate embryos: from ascidians to mice. Microsc. Res. Tech. 69, 160-167. 
8. Wiedenmann, J. and Nienhaus, G. U. (2006) Live-cell imaging with EosFP and other photoactivatable marker proteins of the GFP family. Expert Rev. Proteomics 3, 361-374.

9. Sadikot, R. T. and Blackwell, T. S. (2005) Bioluminescence imaging. Proc. Am. Thorac. Soc. 2, 537-540.

10. Welsh, D. K. and Kay, S. A. (2005) Bioluminescence imaging in living organisms. Curr. Opin. Biotechnol. 16, 73-78.

11. Franco, D., de Boer, P. A., de Gier-de Vries, C., Lamersm W. H., and Moorman, A. F. (2001) Methods on in situ hybridization, immunohistochemistry and betagalactosidase reporter gene detection. Eur. J. Morphol. 39, 169-191.

12. Yang, T. T., Cheng, L., and Kain, S. R. (1996) Optimized codon usage and chromophore mutations provide enhanced sensitivity with the green fluorescent protein. Nucleic Acids Res. 24, 4592-4593.

13. Promega Inc sells synthetic luc2 (Photinus pyralis, see http://www.promega.com/ pnotes/89/12416_07/12416_07.pdf) and hRluc (Renilla reniformis, see http://www. promega.com/pnotes/79/9492_06/9492_06.pdf) genes that are codon-optimised for expression in mammalian cells.

14. Anson, D. S. and Limberis, M. (2004) An improved beta-galactosidase reporter gene. J. Biotechnol. 108, 17-30.

15. Chudakov, D. M., Lukyanov, S., and Lukyanov, K. A. (2005) Fluorescent proteins as a toolkit for in vivo imaging. Trends Biotechnol. 23, 605-613.

16. Miyawaki, A., Nagai, T., and Mizunom H. (2005) Engineering fluorescent proteins. Adv. Biochem. Eng. Biotechnol. 95, 1-15.

17. Bonnerot, C., Rocancourt, D., Briand, P., Grimber, G., and Nicolas, J. F. (1987) A beta-galactosidase hybrid protein targeted to nuclei as a marker for developmental studies. Proc. Natl. Acad. Sci. USA 84, 6795-6799.

18. Sorg, G. and Stamminger, T. (1999) Mapping of nuclear localization signals by simultaneous fusion to green fluorescent protein and to beta-galactosidase. Biotechniques 26, 858-862.

19. Kanda, T., Sullivan, K. F., and Wahl, G. M. (1998) Histone-GFP fusion protein enables sensitive analysis of chromosome dynamics in living mammalian cells. Curr. Biol. 8, 377-385.

20. Miyawaki, A., Nagai, T., and Mizuno, H. (2005) Engineering fluorescent proteins. Adv. Biochem. Eng. Biotechnol. 95, 1-15.

21. van Roessel, P. and Brand, A. H. (2002) Imaging into the future: visualizing gene expression and protein interactions with fluorescent proteins. Nat. Cell. Biol. 4, E15-20.

22. Serganova, I. and Blasberg, R. (2005) Reporter gene imaging: potential impact on therapy. Nucl. Med. Biol. 32, 763-780.

23. Herschman, H. R. (2004) PET reporter genes for noninvasive imaging of gene therapy, cell tracking and transgenic analysis. Crit. Rev. Oncol. Hematol. 51, 191-204. 


\section{Contents}

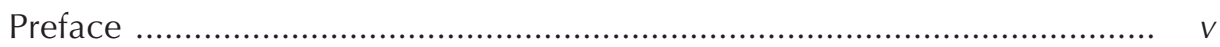

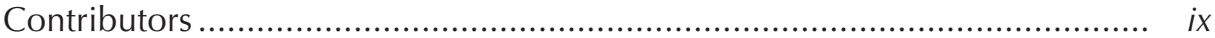

1 Methodologies for Staining and Visualisation of $\beta$-Galactosidase in Mouse Embryos and Tissues

Siobhan Loughna and Deborah Henderson ................................. 1

2 Immunohistochemical Detection of $\beta$-Galactosidase or Green Fluorescent Protein on Tissue Sections

Philip A. Seymour and Maike Sander

3 Detection of Reporter Gene Expression in Murine Airways

Maria Limberis, Peter Bell, and James M. Wilson

4 Three-Dimensional Analysis of Molecular Signals with Episcopic Imaging Techniques

Wolfgang J. Weninger and Timothy J. Mohun

5 Fluorescent Proteins for Cell Biology

George H. Patterson.

6 Detection of GFP During Nervous System Development in Drosophila melanogaster

Karin Edoff, James S. Dods, and Andrea H. Brand

7 Autofluorescent Proteins for Flow Cytometry

Charles G. Bailey and John E. J. Rasko

8 Fluorescent Protein Reporter Systems for Single-Cell Measurements

Steven K. Dower, Eva E. Qwarnstrom, and Endre Kiss-Toth .......... 111

9 Subcellular Imaging of Cancer Cells in Live Mice

Robert M. Hoffman ................................................................... 121

10 Noninvasive Imaging of Molecular Events with Bioluminescent Reporter Genes in Living Subjects

Pritha Ray and Sanjiv Sam Gambhir

11 Green Fluorescent Protein as a Tracer in Chimeric Tissues:

The Power of Vapor Fixation

Harald Jockusch and Daniel Eberhard .......................................... 145

Index ..................................................................................... 155 


\section{Contributors}

Donald S. Anson • Gene Technology Unit, Department of Genetic Medicine, Children, Youth and Women's Health Service, Adelaide, Australia

Charles G. BAiley • Gene and Stem Cell Therapy Program, Centenary Institute of Cancer Medicine and Cell Biology, Australia

Peter Bell • Gene Therapy Program, Department of Pathology and Laboratory Medicine, University of Pennsylvania, USA

Andrea H. BRAND - Wellcome Trust/Cancer Research UK Gurdon Institute and Department of Physiology, Development and Neuroscience, University of Cambridge, UK

James S. Dods • Wellcome Trust/Cancer Research UK Gurdon Institute and Department of Physiology, Development and Neuroscience, University of Cambridge, UK

Steven K. Dower - Section of Functional Genomics, School of Medicine and Biomedical Sciences, University of Sheffield, UK

DANIEL EBERHARD • Department of Biology and Biochemistry, Centre for Regenerative Medicine, Bath University, UK

KarIN EdOFF • Wellcome Trust/Cancer Research UK Gurdon Institute and Department of Physiology, Development and Neuroscience, University of Cambridge, $U K$

SAnjIV SAm GAmbhiR • Molecular Imaging Program at Stanford (MIPS), Departments of Radiology and Bioengineering, Bio-X Program, Stanford University, USA

Robert M. Hoffman - AntiCancer, Inc., San Diego, and Department of Surgery, University of California at San Diego, USA

HaRAld JocKUSCH - Developmental Biology and Molecular Pathology, Bielefeld University, Germany

Dr Deborah Henderson • Institute of Human Genetics, University of Newcastle Upon Tyne, UK

ENDRE KISS-Toth • Cardiovascular Research Unit, School of Medicine and Biomedical Sciences, University of Sheffield, UK

Maria Limberis • Gene Therapy Program, Department of Pathology and Laboratory Medicine, University of Pennsylvania, USA

Dr Siobhan Loughna - School of Biomedical Sciences, University of Nottingham, UK 
Tiмотнy J Mohun • Developmental Biology Division, MRC National Institute for Medical Research, Mill Hill, UK

George H. Patterson - Cell Biology and Metabolism Branch, National Institute of Child Health and Human Development, National Institutes of Health, USA

Eva E. Qwarnstrom - Section of Cell Biology, School of Medicine and Biomedical Sciences, University of Sheffield, UK

JoHn E.J. RAsKo • Gene and Stem Cell Therapy Program, Centenary Institute of Cancer Medicine and Cell Biology, Australia and Cell and Molecular Therapies, Sydney Cancer Centre, Royal Prince Alfred Hospital, Australia

Pritha RAY - Molecular Imaging Program at Stanford (MIPS), Departments of Radiology and Bioengineering, Bio-X Program, Stanford University, USA

MaIKe SANDer - Department of Developmental and Cell Biology, University of California, Irvine, USA

Philip A. Seymour - Department of Developmental and Cell Biology, University of California, Irvine, USA

WolfGAng J WenInger • Integrative Morphology Group, Medical University of Vienna, Austria

James M. WiLson • Gene Therapy Program, Department of Pathology and Laboratory Medicine, University of Pennsylvania, USA 